\title{
Penolakan Allah Dalam 1 Samuel 15:1-35 Beserta Implikasinya
}

\section{God's Rejection In 1 Samuel 15:1-35 And Its Implications}

\author{
Goldy Lie Peruge ${ }^{1)^{*}}$ \\ 1) Mahasiswa Pascasarjana Sekolah Tinggi Filsafat Theologia Jaffray Makassar \\ *Penulis Koresponsdensi: glperuge@gmail.com
}

Received: 0615 2020/ Accepted: 0406 2021/ Published: 07062021

\begin{abstract}
Abstrak
Tujuan dari penulisan ini adalah untuk menjelaskan makna dari penolakan Allah dalam 1 Samuel 15:1-35. Metode yang dipergunakan penulis adalah metode hermeneutik. Hasil dari pembahasan adalah penolakan Allah adalah sesuatu yang kasat mata. Tuhan secara tidak langsung tidak lagi berpihak kepada Saul dalam kepemimpinannya. Ini dikarenakan ketidaktaatan dari Saul sendiri. Beberapa implikasi yang dapat diambil dari pembahasan adalah: Pertama, Allah tidak salah memilih pemimpin-Nya. Ketidaktaatan pemimpin sendiri yang mengharuskan Allah menolak dan tidak berpihak padanya. Kedua, ketaatan harusnya mendasari penyembahan seseorang. Tanpa ketaatan, penyembahan menjadi sia-sia. Ketiga, sebagai hamba-hamba Tuhan, harus ada pertobatan yang sungguh-sungguh.

Kata-kata Kunci: Penolakan, Allah, Saul, Hamba Tuhan.

Abstract

The purpose of this writing is to explain the meaning of God's rejection in 1 Samuel $15: 1-35$. The method used by the author is the hermeneutic method. The result of the discussion is that God's rejection is something visible. God indirectly no longer sided with Saul in his leadership. God's rejection was due to Saul's disobedience. Some implications that can be drawn from the discussion are: First, God did not choose His leader wrong. The leader's disobedience requires God to reject and not take his side. Second, obedience should underlie one's worship. Without obedience, worship is useless. Third, as a servant of God, there must be genuine repentance.
\end{abstract}

Keywords: God, Leaders, Rejection, Saul. 


\section{PENDAHULUAN}

Permasalahan utama yang dibahas dalam artikel ini adalah penolakan Allah terhadap Saul. Dalam 1 Samuel 9 Allah memilih Saul sebagai raja. Allah terlebih dahulu telah berfirman kepada Samuel bahwa ia akan mengurapi seorang raja yang membebaskan umat Allah (ay. 16). Nyatalah di ayat 17, ketika Samuel bertemu dengan Saul, Allah berfirman, "Inilah orang yang Kusebutkan kepadamu itu; orang ini akan memegang tampuk pemerintahan atas umat-Ku." Kisah ini tidak berhenti sampai di sini. Perjalanan kepemimpinan Saul masih panjang dan menyedihkan.

Saul, pemimpin yang gagah perkasa, dalam perjalanan kepemimpinannya menjadi seorang raja yang tidak taat. Saul mempersembahkan korban bakaran secara sembarangan, tanpa mengandalkan Samuel (1 Sam. 13:1-22). Bar mengatakan bahwa ini ancaman terhadap otoritas Samuel sebagai imam (Bar, 2015, p. 333). Ketidaktaatan Saul berlanjut dalam kisah penumpasan orang-orang Amalek (1 Sam. 15). Saul diperintahkan untuk menumpas segala yang ada pada musuh, namun Saul menyisakan ternak-ternak untuk korban persembahan. Sebuah inisiatif yang baik, namun Tuhan berkehendak agar semua ditumpas. Sellars mengungkapkan bahwa ini adalah tindakan "ketaatan"/kesetiaan Saul kepada rakyat, bukan pada Allah (Sellars, 2011, p. 317). Allah menyesal oleh karena Saul. Meskipun berdasarkan penelitian Hermanto sebagian besar orang yang ditelitinya menganggap Allah menyesal layaknya manusia, penyesalan Allah sesungguhnya berbeda dari manusia; sebuah penyesalan yang menuntut ketaatan dari si objek seperti yang dijelaskan Lauled (Hermanto, 2015, p. 11; Lauled \& Maiaweng, 2019, p. 102). Saul akhirnya ditolak Allah. Roh Allah undur dari padanya; roh jahat menghinggapi dia (1 Sam. 16:14). Hal ini seperti yang dipaparkan oleh Manurung; akibat dari ketidaktaatan menimbulkan kemarahan Allah dan hal itu membuat Saul terpisah dengan Allah (Manurung, 2020, p. 324). la menjadi seseorang yang bernafsu untuk membunuh (Daud). Akhir kehidupan Saul ditutup dengan kematian karena bunuh diri (1 Sam. 31:4). Meskipun jelas ini merupakan dikarenakan ketidaktaatan Saul, namun apakah ini menunjukkan ketidak konsistenan Allah? Apakah Allah yang salah memilih? Apa makna penolakan Allah atas Saul? Ini yang penulis coba jawab dalam artikel ini. Penulis menggunakan metode hermeneutik

\section{TEORI}

\section{Latar Belakang Konteks 1 Samuel 15:1-35}

Konteks nas 1 Samuel 15:1-35 adalah peperangan dengan orang Amalek. Saul mendapat suatu perintah langsung dari Tuhan melalui Samuel untuk memusnahkan orang-orang Amalek tanpa ada sisa satu pun. Peperangan dengan orang Amalek ini ada kaitannya dengan Keluaran 17:8-16 di mana Suku Amalek menjadi suku yang pertama menantang Allah dan bangsa Israel di padang gurun. Tetapi Saul tidak mengindahkan apa yang Tuhan perintahkan. Ayat 9 menunjukkan bahwa Saul tidak 
menuruti apa yang Tuhan inginkan. Tuhan menghendaki Saul menumpas semuanya tanpa terkecuali. Saul yang seharusnya menjadi teladan bagi rakyat sebagai seorang pemimpin, sekarang telah membuat hal yang sangat merugikan. Saul mengelak bahwa dia telah bersalah. Saul malah menyalahkan rakyat yang menyuruhnya untuk memaksa melakukan korban bakaran. Saul mencoba membenarkan dirinya dengan mengatakan, bahwa orang banyaklah yang memaksa dia berbuat demikian, tetapi itu hanya dalihnya saja. Allah lebih berkenan melihat ketaatan daripada korban bakaran (Baker, 1979, p. 91). Makna penolakan Allah ini adalah bukti bahwa Allah hanya mengingat raja yang menaati-Nya. Bukan hanya dari perawakannya seperti Israel inginkan, karena Tuhan hanya melihat hati.

\section{Struktur Nas 1 Samuel 15:1-35}

A. Perintah Allah dan Ketidaktaatan Saul (1-9)

1. Perintah Allah untuk menghabisi orang Amalek (1-3)

2. Ketidaktaatan Saul (4-9)

a. Saul mengalahkan orang Amalek (4-7)

b.Saul menyelamatkan Agag dan hewan ternak orang Amalek (8-9)

B. Penolakan Allah (10-35)

1. Berita Penolakan (10-23)

a. Allah Menyesal (10-11)

b.Allah Menolak Saul (12-23)

- Tidak Menumpas habis (12-21)

- Menolak Firman Tuhan (22-23)

2. Respons Saul terhadap Penolakan (24-31)

a. Pengakuan Saul dan permohonan untuk pengampunan dosa (24-25)

b.Saul ditolak Tuhan; Jabatan Saul diberikan kepada orang lain (26-29)

c. Saul meminta untuk Samuel tidak meninggalkan dia (30-31)

3. Perintah Tuhan digenapi (32-33)

4. Pasca Penolakan (34-35)

\section{METODE}

Metode yang digunakan di dalam penelitian ini adalah analisis kualitatif dengan metode hermeneutik (Frederik, 2020, p. 72; Fransisca dan Laukapitang, 2020, p. 103). Hermeneutik Alkitab secara sederhana adalah prinsip-prinsip memahami dan menafsirkan Alkitab (Susanto, 2011, p. 3). Dalam pembahasan, penulis akan melakukan analisis (eksegesis) terhadap struktur 1 Samuel 15:1-35. Setelah itu, penulis akan memaparkan implikasi berdasarkan hasil analisis. 


\section{HASIL DAN PEMBAHASAN}

\section{Analisis Teks 1 Samuel 15:1-35}

\section{Perintah Allah dan Ketidaktaatan Saul (15:1-9)}

Frasa "Aku telah diutus oleh Tuhan" dalam ayat 1 menunjukan peran Samuel yaitu wakil dari Tuhan untuk mengurapi Saul dan ia menyatakan pesan dari Tuhan kepada Saul (Gaebelein, 1984, p. 672). Saul diurapi untuk menjadi raja atas Israel.

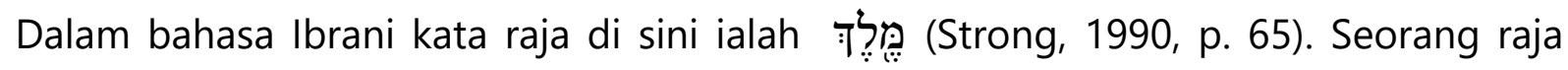
adalah orang yang memberikan perlindungan, keadilan dan belas kasihan, dan merupakan suatu simbol tentang kekuatan dan kekuasaan (Ryken, Wilhoit, \& Longman III, 2011, p. 882).

Dalam ayat 2-3 Tuhan berfirman akan membalas perbuatan orang Amalek

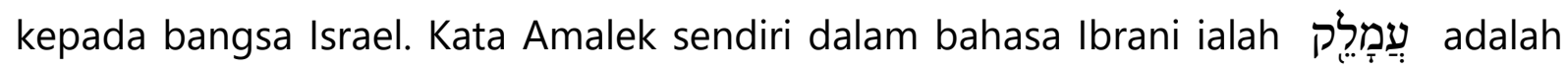
anak Elifas cucu Esau (Kej. 36:12, 16; Douglas, 1992, p. 40). Orang Amalek merupakan musuh bebuyutan Israel. Mereka menyerang Israel ketika berada di Rafidim di dekat Sinai dan membunuh orang-orang tersesat ketika keluar dari Mesir (Pfeiffer dan Harrison, 2004, p. 769). Allah memerintahkan kepada Saul untuk menumpas orang Amalek sebab mereka menghalang-halangi umat Israel keluar dari Mesir. Perintah Allah ialah menumpas orang Amelek. Dalam bahasa Ibraninya sendiri menumpas

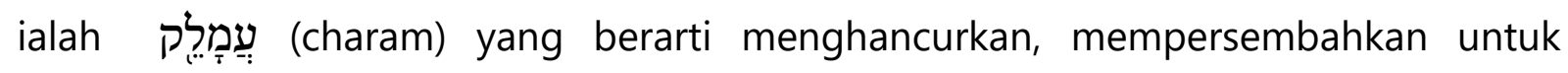
penghancuran (Strong, 1990, p. 789). Tuhan memerintahkan untuk charam orang Amalek yaitu segala yang ada padanya baik itu laki-laki, perempuan, kanak-kanak, bayi, dan hewan ternak. Jadi, yang Tuhan maksud adalah tidak ada yang boleh tersisa dari orang Amalek.

Saul menyiapkan pasukannya untuk berperang melawan bangsa Amalek dengan cara memanggil rakyat untuk berkumpul dan memeriksa setiap barisan (ay. 4-5). Pasukan Saul berjumlah dua ratus sepuluh ribu. Telaim terletak beberapa kilometer di sebelah selatan Bersyeba. Kota ini sangat dekat dengan dengan Yehuda sehingga mudah bagi Yehuda untuk mengirim pasukannya. Kota yang dimaksudkan dalam ayat 5 merupakan desa yang diperkuat dengan benteng pertahanan, sebab bangsa Amalek hidup mengembara (Guthrie, 1982, p. 460).

Dalam ayat 6 Saul berbicara dengan orang-orang Keni. Orang Keni adalah satu suku bangsa Midian (Bil. 10:29; Hak. 1:16; 4:11). Nama itu berarti tukang besi. Orang Keni muncul pertama kali sebagai penduduk pada zaman leluhur di Kanaan (Kej. 15:19). Orang Keni menyertai Suku Yehuda mendiami pusaka mereka (Hak. 1:16; 1 Sam. 27:10; Douglas, 1992, p. 544). Menurut Tafsiran Wycliffe "Pelayanan Yitro, orang Keni kepada orang Israel pada masa penggembaraan telah menimbulkan suatu ikatan yang kuat di antara orang Isarel dengan orang Keni. Mereka telah mendampingi orang Israel sampai ke Yerikho, dan sesudah itu mereka tinggal bersama dengan orang Amalek di padang gurun sebelah selatan Yehuda" (Pfeiffer 
dan Harrison, 2004, p. 770). Karena persahabatan mereka dengan orang Israel pada waktu mereka keluar dari Mesir itulah yang membuat Saul membiarkan mereka pergi dari tengah-tengah orang Amalek sehingga mereka tidak lenyap bersama dengan orang Amalek.

Di ayat 7, diinformasikan bahwa Saul mengalahkan orang Amalek dari Hawila sampai Syur. Menurut Ensiklopedi Masa Kini, ungkapan dari "Hawila sampai ke Syur" maksudnya ialah tanah yang didiami oleh orang-orang Ismael (Kej. 25:18; Douglas, 1992, p. 373). Saul akhirnya mengalahkan orang Amalek. Mula-mula Saul menaati perintah Samuel, namun kemudian ia mengubah sikap. Raja orang Amalek yaitu Agag dibiarkan hidup sedangkan rakyatnya dibunuh. Tidak hanya itu, hewan ternak yang berkualitas baik juga tidak dibunuh, melainkan diambil oleh raja Saul. Dengan kata lain Saul tidak menaati perintah yang telah disampaikan oleh Samuel. Agag raja orang Amalek itu tidak dibunuhnya agar bisa dibawa untuk menjadi tawanan ke istananya untuk mempertinggi kemuliaannya. Begitu juga dengan barang jarahan mereka yaitu hewan ternak yang paling bagus, hanya hewan ternak yang jelek dan tak terpakai yang dibunuh (Baker, 2004, p. 486).

\section{Penolakan Allah terhadap Saul (1 Sam. 15:10-35)}

\section{Berita Penolakan (ay. 10-23)}

Dalam ayat 10-12, kata menyesal (נָָָָ nakham) adalah kata kerja nifal atau bentuk pasif, yang mana subjek dikenakan pekerjaan. Jika diterjemahkan secara gramatikal, maka Allah menyesal berarti 'menyesal' yang ada pada diri Allah disebabkan oleh keadaan atau situasi di sekitar-Nya yang mengakibatkan-Nya menyesal atau merubah niat atau tindakan yang telah dilaksanakan atau direncanakan-Nya (Maiaweng, 2011, p. 101). Tafsiran Alkitab Masa Kini mengatakan "Allah sedih dan berubah sikap" (Guthrie, 1982, p. 460). Sedangkan tafsiran Wycliffe mengatakan "Dalam PL, Allah dikatakan 'menyesal' ketika perubahan watak dan perilaku dari orang yang diperhatikan oleh-Nya membuat Dia harus mengubah rencana dan maksud-Nya terhadap mereka" (Pfeiffer dan Harrison, 2004, p. 770). Melalui penyesalan Allah ini Samuel pun merasa sakit hati. Samuel kaget mendengar Firman Tuhan, dan semalam-malamnya itu ia meraung-raung kepada Tuhan untuk keselamatan dan kemampunan bagi Saul (Baker, 2004, p. 486). Pada akhirnya Samuel pun pergi menemui Saul untuk memberitahukan perkataan Tuhan. Namun Saul pergi ke Karmel untuk mendirikan suatu tanda yaitu monumen untuk mengingat kemenangannya. Lalu Saul pergi ke Gilgal tempat di mana kerajaan Saul juga ditegaskan (11:14; Baker, 2004, p. 771).

Ketika Samuel datang, Saul menyambut Samuel seolah-olah ia tidak melakukan kesalahan. Saul melaporkan bahwa ia telah melaksanakan perintah Tuhan. Namun Samuel mengatakan bahwa ia mendengar suara-suara hewan. Seharusnya Saul langsung mengakui apa yang dia lakukan, tetapi ia malah menyalahkan rakyatnya seolah-olah ia tidak melakukan kesalahan. "Sebab rakyat menyelamatkan kambing..." 
(ay. 15). Kalimat ini menyatakan bahwa Saul berusaha untuk mengalihkan tanggung jawab pribadinya kepada orang lain (Baker, 2004, p. 772). Saul mengatakan bahwa hewan yang menjadi korban jarahan adalah dimaksudkan untuk korban. Tapi setiap orang yang membawa korban biasanya mendapat bagiannya masing-masing. Justru sebenarnya hewan-hewan yang akan dipersembahkan untuk Tuhan sangat jelas dilarang (Guthrie, 1982, p. 461).

Setelah Samuel mendengarkan alasan Saul, maka ia menyampaikan perkataan Tuhan yang ia dengar tadi malam. Ketika Saul merasa "dirinya kecil dan tidak berarti," Allah telah menjadikan ia menjadi raja Israel (ay. 17). Menurut tafsiran Wycliffe, ungkapan tersebut adalah ucapan Saul tentang dirinya ketika ia mendengar cerita Samuel bahwa ia telah dipilih untuk memimpin kerajaan Israel (Pfeiffer dan Harrison, 2004, p. 771). Samuel mengingatkan kembali bahwa Saul adalah orang yang diurapi menjadi raja atas Israel. Samuel mengulang kembali isi dari perintah Tuhan, yaitu untuk membinasakan orang-orang Amalek tanpa tersisa satu pun. Dalam ayat 19, Samuel bertanya mengapa Saul mengambil jarahan dan melakukan perbuatan yang jahat di mata Tuhan.

Dalam ayat 20-21, Saul menjawab Samuel bahwa ia telah mendengarkan perintah Tuhan. Bagi Saul perbuatannya mengambil jarahan adalah perbuatan yang benar. Hal ini mungkin didasari oleh tradisi perang zaman itu. Menurut tradisi, ketika memenangi sebuah peperangan maka pemenang dari perang tersebut berhak mengambil jarahan dan itu merupakan suatu aturan mendasar dari masalah perang. Pengambilan piala kemenangan dari musuh mempunyai hubungan erat dengan upacara. Itu dapat terdiri dari senjata atau kepala atau bahkan pemimpin yang masih hidup dari pasukan lawan yang dibawa pulang untuk dipertontonkan kepada publik (Ryken, Wilhoit, \& Longman III, 2011, p. 671-672). Jarahan yang diambil oleh Saul digunakan untuk mempersembahkan korban kepada Tuhan.

Samuel berkata dalam ayat 22 bahwa pengorbanan itu tidak penting, tetapi pengorbanan akan diterima jika membawanya dengan sikap taat dan kesetiaan kepada Tuhan (McMahan, 1985, p. 397). Samuel menekankan bahwa persembahan yang dilakukan harus disertai dengan ketaatan. Bagi Samuel, ketaatan merupakan elemen yang penting dibandingkan dengan persembahan yang dilakukan oleh Saul. Bagi Samuel untuk apa mempersembahkan itu semua kepada Tuhan, jika tidak menaati perintah Tuhan.

Samuel melanjutkan perkataannya dengan menyinggung perihal "pendurhakaan" (ay. 23). Pendurhakaan dan bertenung merupakan bentuk kemurtadan; yang satu melanggar otoritas Allah, yang lainnya mengakui adanya kekuatan adikodrati yang lain dari Allah (Pfeiffer dan Harrison, 2004, p. 771). Dosa "bertenung" artinya berusaha untuk memanipulasi peristiwa, orang, atau masa depan dengan mempergunakan roh-roh orang yang sudah mati (Stamps, 2000, p. 442). Saul disebut sebagai orang yang berbuat kedegilan. "Kedegilan" adalah orang yang pembangkang atau keras kepala. Bagi Samuel, Saul telah menjadi orang yang sangat durhaka dan degil. Kedegilan Saul tersebut maka secara tidak langsung ia sudah 
menolak Firman Tuhan. Pada pasal $(13: 13,14)$ Samuel telah mengatakan bahwa keturunan Saul tidak akan mewarisi takhta kerajaan, namun sekarang jabatannya sebagai raja pun telah ditolak oleh Allah. Saul menjadi orang yang keras kepala oleh karena ketidaktaatannya kepada Firman Tuhan.

Jika kembali kepada teks, penolakan yang dilakukan oleh Saul dilakukan secara langsung ketika Samuel menyampaikan firman Tuhan kepadanya. Sedangkan penolakan Tuhan, itu mengacu kepada sesuatu yang belum terjadi secara kasat mata. Dalam arti Saul tidak langsung berhenti menjadi raja Israel pada saat itu. Bangsa Israel masih melihat Saul sebagai raja mereka. Tetapi di hadapan Tuhan, Saul telah digantikan dengan orang yang berkenan di hati Tuhan (13:14). Secara tidak langsung Tuhan sudah tidak berpihak kepada Saul.

\section{Respons Saul Terhadap Penolakan (ay. 24-31)}

Saul berusaha untuk memperoleh pengampunan, tapi mungkin tidak segenap hati. Itu dapat dilihat melalui responsnya dengan menyalahkan orang lain. la mengatakan "tetapi aku takut kepada rakyat" (ay. 24). Ini menandakan bahwa ia menyalahkan orang lain atas pelanggaran yang ia buat. la memang telah mengakui perbuatannya, tetapi ia tidak sungguh-sungguh. la hanya takut kepada rakyat tetapi tidak takut kepada Tuhan. Ini selaras yang diutarakan Sellars; Saul takut kepada rakyat menunjukkan bahwa ia lebih taat kepada mereka ketimbang kepada Allah (Sellars, 2011, p. 317).

Saul memohon kepada Samuel untuk tidak pergi meninggalkan dia, namun ia menolak karena Saul sudah melanggar firman Tuhan. Saul memegang punca jubah hingga robek yang mengibaratkan tentang kerajaan Saul yang akan dirobekan juga (ay. 27-28; Baker, 1979, p. 48). "Sang Mulia dari Israel..." (ay. 29) merupakan sebutan khas untuk Allah yang menekankan sifat abadi yang dimiliki oleh Allah tentang keadaanya yang tidak berubah (Guthrie, 1982, p. 461). Lalu sekali lagi Saul memohon agar Samuel ikut bersama dengan dia untuk mendapat hormat di hadapan tua-tua Israel. Meskipun Saul sudah ditolak menjadi raja oleh Tuhan dan Samuel tetapi ia masih tetap raja orang Israel.

"la tidak tahu menyesal, sebab ia bukan manusia yang harus menyesal" dalam ayat 29 merujuk kepada kesetiaan Allah kepada Israel bahwa la akan tetap menjadi sekutu Israel selama-lamanya. Tuhan Allah memegang teguh apa yang pernah diucapkan-Nya. Tidak ada yang boleh mengeraskan hatinya untuk menggagalkan rencana Allah. Karena Saul melakukan hal yang demikian maka ia ditolak oleh Tuhan. Allah tidak pernah menyesali keputusan-Nya untuk menjadi sekutu Israel, maka Tuhan menyesalkan perbuatan Saul yang membahayakan keputusan Allah untuk menjadi sekutu Allah (Hadiwijono, 2006, p. 96).

\section{Perintah Tuhan Digenapi (ay. 32-33)}

Menurut tafsiran Wycliffe, kalimat "Dengan gembira Agag pergi kepadanya..." (ay. 32) terjadi perubahan terjemahan. Ada yang mengatakan bahwa "Agag datang 
dalam belenggu," ada juga yang menerjemahkan, "Agag datang dari belakang". Ada juga yang berpikir bahwa Agag melakukan tarian kematian. Kata Ibrani yang dipakai sangat tidak jelas artinya (Pfeiffer dan Harrison, 2004, p. 771). Dalam ayat ini penggenapan firman Tuhan harus tergenapi. Samuel membunuh Agag oleh karena dosa-dosa yang orang Amalek lakukan dahulu dan dosa Agag sendiri yang berkalikali memasuki dan merampok di wilayah Israel (Baker, 1979, p. 488). Untuk itu Samuel membunuh Agag raja orang Amalek sebagai upacara agamawi sebagai kegenapan "pengorbanan" bangsa Amalek untuk Allah (Guthrie, 1982, p. 462).

\section{Pasca Penolakan (ay. 34-35)}

Ini adalah akhir dari perjumpaan Saul dan Samuel. Mereka berpisah ke tempat mereka masing-masing. Samuel pulang kembali ke Rama dan Saul pergi ke Gibea. Samuel sangat sedih oleh apa yang sudah Saul perbuat. la sangat berdukacita karena ia sendiri telah mengurapi Saul. Sekali lagi penulis kitab Samuel mengatakan bahwa Allah telah menyesal telah menjadikan Saul raja.

\section{Kesimpulan}

Dari hasil analisis struktur di atas, penolakan Tuhan kepada Saul adalah penolakan yang mengacu kepada ketidaktaatan Saul. Selain itu yang menarik ini adalah penolakan Allah yang kasat mata, berbeda dari penolakan langsung Saul kepada Samuel. Tuhan secara "tidak terlihat" tidak lagi berpihak kepada Saul sebagai seorang raja yang masih menjabat.

\section{Implikasi Penolakan Allah bagi Hamba-hamba Tuhan}

\section{Allah Tidak Pernah Salah dalam Memilih Hamba-Nya}

Hal pertama yang ingin penulis sampaikan bahwa Allah tidak pernah salah dalam memilih hamba-hamba-Nya untuk melayani-Nya. Kata Hamba dalam PL berasal dari kata Ibrani עֶבֶד (eved) yang berarti budak, hamba, pelayanan. Artinya, seseorang yang bekerja untuk keperluan orang lain, untuk melaksanakan kehendak orang lain. la adalah pekerja yang menjadi milik tuannya. Di luar Alkitab kata itu berarti; hamba yang melayani raja; bawahan dalam politik; keterangan tentang diri sendiri untuk menunjukan kerendahan hati; dan hamba-hamba dalam kuil-kuil kafir (Salong, 2012, p. 228).

Dalam kehidupan keagamaan, bangsa Israel, kata itu dipakai untuk menunjukan kerendahan diri seseorang di hadapan Allah (seperti dalam Kel. 4:10, Mzm. 119:17; 143:12). Pemakaian itu juga menyatakan rendahnya kedudukan pembicara, juga menyatakan tuntutan ilahi yang mutlak terhadap seorang anggota dari umat yang Tuhan pilih dan kepercayaan yang bersesuaian dengan itu dalam penyerahan diri kepada Allah, ia akan membela hamba-Nya. Dalam bentuk jamak arti kata itu ialah orang-orang saleh (Mzm. 135:14; Salong, 2012, p. 228). Dari pemahaman- 
pemahaman tersebut, penulis menyimpulkan seeorang Hamba Tuhan adalah orang yang bekerja dan melayani untuk Tuhan dan seorang hamba adalah orang yang mengabdi sepenuhnya kepada Allah.

Allah memiliki kedaulatan dalam kehidupan setiap manusia. la memiliki otoritas yang mutlak dan memerintah atas ciptaan-Nya (Boice, 2011, p. 123). Dalam PL cara Allah memanggil hamba-hamba-Nya dengan cara yang begitu spesial. Yesaya terpanggil terdapat dalam Yesaya 6:8. Tuhan bertanya dan Yesaya menjawab, "Ini aku, utuslah aku." Secara tidak terduga Allah memanggil Musa. Dalam Keluaran 3:14 Allah menampakan diri dalam nyala api yang keluar dari semak duri dan berkata, "Aku adalah Aku." Lagi firman-Nya: "Beginilah kaukatakan kepada orang Israel itu: Akulah Aku telah mengutus aku kepadamu." Dalam PB Tuhan Yesus memanggil secara khusus memanggil orang yang menyerahkan diri secara purna waktu. Dalam Matius 4:21-22 Tuhan berkata kepada Matius yang sedang duduk di tempat pemungut cukai, "Ikutlah Aku". Dalam Matius 9:9 Petrus dan Andreas dipanggil pada waktu mereka menjala ikan. "Mari ikutlah Aku, dan kamu akan kujadikan penjala manusia." Meskipun di bawah pimpinan Roh Kudus, panggilan Tuhan untuk masa kini agak berbeda, tidak lagi menggunakan penglihatan atau langsung memanggil, dan secara prinsip tidak berubah (Han, 1998, p. 4-5).

Pemilihan Saul sebagai raja terbilang unik (1 Sam. 9). Oleh karena rakyat Israel telah menolak Allah sebagai raja mereka maka Allah meluluskan permintaan mereka. Allah mengurapi Saul sebagai raja melalui Samuel yang pada saat itu menjadi hakim atas Israel Saul-lah yang Allah tunjuk sebagai raja Israel. Lalu jika Allah memilih dan mengurapi Saul, lalu mengapa pada akhirnya Allah menyesal? Apakah Allah tidak konsisten dengan apa yang la katakan?

Tuhan memanggil hamba-hamba-Nya dari masa ke masa dengan cara yang berbeda-beda, unik dan spesial. Setiap orang yang terpanggil sudah masuk dalam rancangan Allah. Panggilan Tuhan akan memberi jaminan bahwa jika ia memanggil, maka la akan memakai dan jika ia memakai, maka la secara langsung bertanggung jawab dan memelihara untuk tidak jatuh (Han, 1998, p. 16). Tuhan tidak pernah salah dalam memilih setiap orang yang akan dipilihan-Nya karena la sudah berjanji akan pemeliharaan-Nya dalam kehidupan orang yang terpanggil. Sitanggang mengungkapkan bahwa ini merupakan cara Allah untuk menyampaikan maksudnya kepada manusia; digolongkan sebagai akomodasi (Sitanggang, 2018, p. 50).

Allah menyesal berarti Allah berubah sikap oleh karena perubahan keadaan di sekitar-Nya. Saul telah menolak la, maka Allah menolak Saul. Saul tetap menjadi raja hingga akhir hidupnya, tetapi ia sudah tidak berkenan di hadapan Allah. Allah menyesal bukan berarti dia salah memilih Saul, melainkan oleh karena perbuatan Saul yang tidak sesuai dengan kehendak-Nya maka la merubah sikap dan rancangan-Nya. Jadi, bukan berarti Allah tidak konsisten, melainkan oleh karena kesalahan Saul maka la yang Maha Mulia merubah rancangan-Nya untuk Israel. 


\section{Fokus Terhadap Penyembahan tetapi Melupakan Ketaatan}

Sudah sewajibnya sebagai orang percaya untuk memberikan persembahan korban syukur kepada Tuhan. Namun apapun bentuknya Tuhan menginginkan persembahan disertai dengan ketaatan firman-Nya. Penyembahan adalah sisi rohani dari penyerahan diri, penundukan diri dan keterikatan dari berbagai hal (Redman, 2005, p. 15). Dalam PL, pada dasarnya kurban dan persembahannya merupakan cara untuk menjalin kembali hubungan dengan Tuhan, sebagai persembahan yang berbau harum, sebagai pengakuan dosa dan salah dan untuk menyenangkan hati Allah (Kej. 28:20-22; Kel. 29:25; Mal. 3:6-12). Namun seringkali persembahan dan upacara kurban yang semula merupakan ungkapan pertobatan dan kepercayaan itu sering merosot dan hanya menjadi upacara lahiriah tanpa diiringi hati yang menyesal, bertobat, adil dan berbelas kasihan. Dalam hal ini kurban dan persembahan itu tidak ada artinya di hadapan Allah (Herlianto, 2003, p. 60).

Ketaatan adalah sebuah kewajiban bagi hamba Tuhan yang telah terpanggil untuk melayani-Nya. Seakan-akan ketaatan merupakan harga mati seorang hamba Tuhan. Ketaatan hanya dapat dilakukan jika seorang yang percaya yakin akan janji dan firman Tuhan. Bukan hanya sekadar menuruti perintah tetapi harus disertai dengan sikap tunduk kepada Tuhan. Namun, seringkali para hamba Tuhan meragukan perkataan atau janji Allah. Hal itu akan menimbulkan kekhawatiran sehingga dapat membuat seseorang menjadi takut dan ragu. Ketakutan dan keraguan itulah yang membuat seseorang akan tidak menjadi taat dan mempercayai firman Tuhan.

Saul bermaksud baik untuk tidak menumpas habis segala macam ternak yang baik karena ia menggunakannya hanya untuk mempersembahkannya kepada Tuhan selesai ia berperang. Perintah Tuhan kepada Saul melalui Samuel adalah menumpas habis seluruh orang Amalek berserta hewan ternaknya. Saul tidak menaati Firman Tuhan karena apa yang ia lakukan sangat bertentangan dengan firman Tuhan. la takut terhadap rakyatnya. la tidak takut akan Tuhan. Menaati firman Tuhan dengan segenap hati adalah lebih baik dari pada penyembahan, pelayanan atau pengorbanan yang pribadi lahiriah. Ini berarti bahwa penyembahan, doa, puji-pujian, karuniakarunia rohani, dan pelayanan kepada Allah tidak berharga dalam pandangan-Nya jikalau tidak disertai ketaatan tegas kepada Allah dan standar kebenaran-Nya (Stamps, 2005, p. 442). Oleh karena itu sebagai orang yang memiliki iman kepada Allah maka sikap penyembahan kepada Allah harus didasari ketaatan dan jika tidak maka itu adalah sia-sia.

\section{Tidak Sungguh-sungguh Bertobat di Hadapan Tuhan}

Dalam PL kata tobat menggunakan bahasa Ibrani שוּב (syuv) yang berarti: berpaling dan kembali kepada Tuhan. Dalam septuaginta kata Ibrani itu

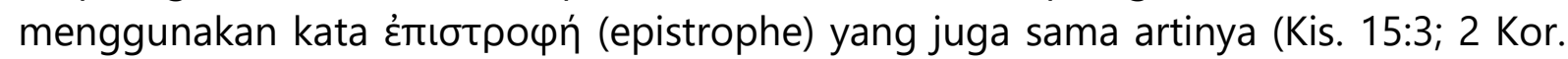
3:16; Luk. 1:16-17). Tetapi pada Perjanjian Baru ada satu kata Yunani lagi yang 


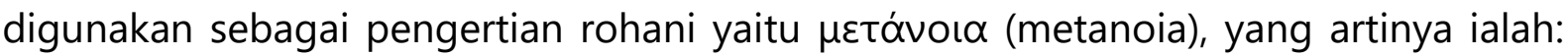
perubahan hati atau perubahan niat. Kata kerja yang bersangkut paut dengan kata "metanoia" itu pernah diterjemahkan dengan "menyesal" (Luk. 17:3). Ini berarti pertobatan adalah berpaling kembali kepada Tuhan (van Niftrik dan Boland, 1984, p. 493).

PL menekankan bahwa cakupan pertobatan melebihi dukacita-penyesalan dan perubahan tingkah-laku lahiriah dalam keadaan apapun pertobatan yang sungguh kepada Allah mencakup merendahkan batiniah, perubahan hati sungguh dan benarbenar merindukan Allah disertai pengenalan yang jelas dan baru akan diri-Nya dan jalan-Nya (Douglas, 1992, p. 486).

Pertobatan hanya dialami oleh orang yang sudah memikirkan hidupnya sendiri dan menentukan sikap terhadap masa depan. Keduanya harus dilakukan dengan sadar. Charlie Riggs dalam bukunya menjelaskan tentang perbuatan Saul. Saul telah dipilih menjadi pemimpin Israel. Pasal 10 la dijanjikan Roh yang menjadikan dia pribadi yang baru; dengan cara hidup, tujuan hidup, hati dan motivasi baru. Tetapi, dalam pasal 13 Saul melakukan tindakan ketidaktaatan. Akibatnya, Allah memilih seorang lain untuk menggantikannya. Riggs mengungkapkan sepertinya ia mendapat kesempatan kedua dalam pasal 15. Namun, Saul kembali tidak taat dan melemparkan kesalahan ke orang lain (ay. 20-21). Samuel memperingatkan bahwa ia akan kehilangan takhtanya. Dalam kehidupan selanjutnya dari Saul, dapat dilihat bahwa jiwanya terganggu oleh kecemburuan pada Daud (18:6-9). Dia berusaha membunuh Daud. Dia berakhir menjadi seorang pemimpin yang tidak lagi bersekutu dengan Allah (Riggs, 2005, p. 118-119). Dapat disimpulkan dari pernyataan tersebut bahwa sebagai hamba yang dipilih oleh Allah harus ada penyesalan yang sungguh-sungguh. Jika tidak itu dapat menimbulkan perbuatan dosa yang lain jika tidak diakui dengan sungguh-sungguh. Denver Sizemore dalam bukunya mengatakan "Banyak orang mengira bahwa rasa ketakutan dan gentar yang dialami itu adalah pertobatan, tetapi berdasarkan penemuan, sedikit sekali yang menunjukkan bahwa mereka benar-benar bertobat. Perasaan takut bukanlah pertobatan (Sizemore, 2008, p. 92).

Hanya sedikit dari Hamba-hamba Tuhan yang bersedia berhadapan dengan dosa, sebagai akar dari berbagai masalah. Kebiasaan untuk mencari alasan, menyalahkan lingkungan, menyalahkan orang lain, menyalahkan Allah tetapi tidak pernah bersedia mengakui bahwa diri sendiri berdosa (Soedarmo, 1985, p. 165). Untuk menjadikan pertobatan itu komplit harus ada "perubahan" dan "pembaharuan" kehidupan (Sizemore, 2008, p. 89).

Sesungguhnya semua hamba Tuhan pasti pernah berbuat dosa. Namun, bagi Tuhan, yang terutama adalah pertobatan. Hati yang remuk karena menyadari dosadosanya di hadapan Tuhan jauh lebih penting dan bermakna dibandingkan segala perbuatan baik dan segala persembahan korban (Mzm. 51:18, 19; Sihotang, 2005, p. 144). 


\section{KESIMPULAN}

Hasil dari pembahasan di atas, terlihat bahwa penolakan Allah adalah sesuatu yang kasat mata. Tuhan secara tidak langsung tidak lagi berpihak kepada Saul dalam kepemimpinannya. Beberapa implikasi yang dapat diambil dari pembahasan adalah: Pertama, Allah tidak salah memilih pemimpin-Nya. Ketidaktaatan pemimpin sendiri yang mengharuskan Allah menolak dan tidak berpihak padanya. Kedua, ketaatan harusnya mendasari penyembahan seseorang. Tanpa ketaatan, penyembahan menjadi sia-sia. Ketiga, sebagai hamba-hamba Tuhan harus ada pertobatan yang sungguh-sungguh.

\section{KEPUSTAKAAN}

Baker, David L. (2005). Mari Mengenal Perjanjian Lama. Bandung: BPK Gunung Mulia. Bar, Shaul. (2014). Saul and Samuel. The Expository Times, 126(7), 326-333. DOI:

$10.1177 / 0014524614564288$.

Douglas, J. D. (Ed). (1992). Ensiklopedi Masa Kini Jilid 1 A-Z. Jakarta: Yayasan Komunikasi Bina Kasih/OMF.

Fransisca, Delvy \& Yunus D. A. Laukapitang. (Desember 2020). Kepemimpinan Yosia

Berdasarkan Kitab 2 Tawarikh 34:1-7 dan Implikasi Bagi Kepemimpinan Pemuda

di Gereja. Jurnal Ilmu Teologi dan Pendidikan Agama Kristen, 1(2), 103-122.

https://ojs.sttjaffray.ac.id/jitpk/article/view/508/pdf_7.

Frederik, Hanny. (2020). Prinsip-Prinsip Kepemimpinan Penggembalaan Berdasarkan

Yohanes 10:1-21 dan Implementasinya dalam Kepemimpinan Gereja. Jurnal Ilmu

Teologi dan Pendidikan Agama Kristen, 1(2), 69-86.

https://ojs.sttjaffray.ac.id/jitpk/article/view/487/pdf_5.

Han, Yap Un. (1998). Problematika Hamba Tuhan. Jakarta: Persekutuan Alumni SBC.

Hermanto, Bambang Wiku. (Juni 2015). Pengertian Orang Percaya Tentang Ungkapan

"Allah Menyesal." Jurnal Simpson, 2(1), 11-36.

https://journal.sttsimpson.ac.id/index.php/Js/article/download/18/17.

Lauled, Mershy Christiana \& Peniel C. D. Maiaweng. (2019). Kajian Naratif Teologi

Allah Menyesal Berdasarkan 1 Samuel 15:1-35 Dan Implikasinya Dalam

Kehidupan Orang Percaya. Repository Skripsi Online, 1(2), 102-109.

https://skripsi.sttjaffray.ac.id/index.php/skripsi/article/view/31.

Maiaweng, Peniel C. D. (2014). Penafsiran Narasi Perjanjian Lama. Makassar: Sekolah

Tinggi Theologia Jaffray.

Manurung, Kosma. (Desember 2020). Memaknai Kemarahan Allah Dari Sudut

Pandang Teologi Pentakosta Di Era Post Modern. VISIO DEI: Jurnal Teologi

Kristen, 2(2), 307-328.

http://jurnal.sttstarslub.ac.id/index.php/js/article/download/162/36/.

Pfeiffer, Charles F. dan Harison, Everett F. (2004). Tafsiran Alkitab Wycliffe Vol 1

Kejadian-Ester. Malang: Gandum Mas. 
Sellars, Dawn Maria. (2011). An Obedient Servant? The Reign of King Saul (1 Samuel 13-15) Reassessed. Journal for the Study of the Old Testament, 35(3), 317-338. https://doi.org/10.1177/0309089211398710.

Sitanggang, Murni Hermawaty. (Mei 2018). Kajian Terhadap Kemungkinan Allah Menyesal dan Berubah Pikiran. Epigraphe: Jurnal Teologi dan Pelayanan Kristiani, 2(1), 50-60.

http://www.stttorsina.ac.id/jurnal/index.php/epigraphe/article/download/20/16. Susanto, Hasan. (2011). Hermeneutik: Prinsip dan Metode Penafsiran Alkitab. Malang: Literatur SAAT. 